\title{
The Sefer Torah and Jewish Orthodoxy in the Islamic Middle Ages
}

\section{Introduction}

Between the period of the Second Temple and the early Middle Ages, reflected in the two great collections of the Dead Sea Scrolls and the Cairo Genizah, a change happens in Judaism's transmission of its scripture. The texts from Qumran reflect a society necessarily wedded to the scroll as the medium for transmitting the Hebrew Bible (for more on the Qumran materials, see Chapter 1 from Krauß and Schücking-Jungblut). In the ensuing centuries, even as surrounding cultures adopted the codex, this necessity was fixed, regulated and formalized into a set of halakhic prescriptions for the copying and reading of the Torah scroll, the only acceptable medium for the recitation of God's law in rabbinic Judaism of late antiquity (on this, see the essay from del Barco in the present volume). Yet, by the Middle Ages, the Cairo Genizah reveals a Jewish community that had embraced the codex with an impressive enthusiasm, evidenced by the tens of thousands of leaves from books big and small that were deposited into the genizah chamber of the Synagogue of the Jerusalemites in al-Fustāt. What occasioned such a shift in the Jewish relationship to the book? Does the heterogeneous manuscript evidence of the Genizah provide a clear answer, or did the medieval Judaism of the Islamic east, divided as it was between Rabbanite and Qaraite, Palestinian and Babylonian, possess a complex relationship with the new medium?

\section{The Sefer Torah}

The Torah scroll, the Sefer Torah, occupies a pre-eminent position in Judaism's cultural consciousness by dint of long tradition and frequent repetition of codified rites. Reverence and sanctity have accrued to it as a physical object, and respect is paid to it during its useful lifetime and even on its "death". The synagogue congregation stand in the Sefer Torah's presence. One should not produce a Torah scroll thoughtlessly, but with careful and full intent; nor needlessly sell one. Public reading from the scroll marks not only the passing of weeks, and the celebration of holy and high holy days, but also cements an individual's transition into adulthood. In antiquity, public reading of the Torah scroll was a sign of authority enjoyed by Jewish kings and high priests (Mišna Soṭa 7:8; Yoma

Ә Open Access. (c) 2020 Ben Outhwaite, published by De Gruyter. (B)BY-NC-ND This work is licensed under a Creative Commons Attribution-NonCommercial-NoDerivatives 4.0 International License.

https://doi.org/10.1515/9783110634440-005 
7:1); with the dispersion, and the rise of the synagogue, possession of a Sefer Torah denoted a congregation, and thereby a community. In the synagogue, the Torah scroll stands at the centre of the principal rite, the reading of the weekly portion of the Pentateuch, and special prayers accompany its introduction into the service, and its subsequent withdrawal from it. ${ }^{1}$ Some congregations raise and lower the scroll, before or after the reading, receiving a scriptural response in reply; other practices have grown up over time. ${ }^{2}$ In late antiquity the main Jewish legal sources, the Mišna and Talmuds, discussed the correct form, treatment and disposal of the Sefer Torah. A scroll's creation, from the production of the parchment to the ornamenting of the letters, is set out in dedicated treatises such as Sofrim or the minor tractate Sefer Tora. Failure to follow these prescriptions can result in a scroll that is פסול (pasul), "blemished, defective”, i.e., liturgically invalid. Even scrolls that are at the end of their useful life retain their sanctity and must be treated appropriately: ואמר רבא ספר תורה שבלה גונזין אותו אצל תלמיד חכם, "And Rava said: 'A Sefer Torah that is worn out should be interred with a scholar'” (Babylonian Talmud Megilla 26b). The Torah's sanctity gives the scroll a totemistic value: the Mišna decrees that a king heading off to fight should take along his Torah scroll (Mišna Sanhedrin 2:4). According to the historian Josephus, the Romans turned this back on the Jews by parading a captured scroll as plunder through Rome, following the legions' victory in the Great Revolt, a detail which perhaps Josephus added as embellishment to underline the definitive nature of the Jewish defeat. ${ }^{3}$

These cumbersome rolls of animal skins derive their prestige from their weighty contents, the Law of Moses, the first five books of the Hebrew Bible. In Rabbinic Judaism the Sefer Torah was "the only suitable and appropriate receptacle of the Holy Writ," ${ }^{4}$ and it was expected to contain the entire text of the Hebrew Pentateuch, unchanged and unabbreviated. Any suspicion that this might not be the case could render a scroll invalid, for instance, if it had been purchased from a non-Jew or there were too many errors or erasures. ${ }^{5}$ Manuscript discoveries suggest that this rabbinic stipulation was probably not

1 Ismar Elbogen, Jewish Liturgy: A Comprehensive History, trans. Raymond P. Scheindlin (Philadelphia: Jewish Publication Society; Jewish Theological Seminary of America, 1993), 158-63.

2 Elbogen, Jewish Liturgy, 142.

3 Simon Schama, The Story of the Jews: finding the words, 1000 BCE-1492 CE (London: Vintage Books, 2014), 153-54.

4 Menahem Haran, "Bible Scrolls in Eastern and Western Jewish Communities from Qumran to the High Middle Ages,” Hebrew Union College Annual 56 (1985): 22.

5 Elbogen, Jewish Liturgy, 142. Aaron Rothkoff and Louis Isaac Rabinowitz, "Sefer Torah," in Encyclopaedia Judaica, ed. Fred Skolnik and Michael Berenbaum (Detroit: Macmillan Reference USA, 2007): 243. 
operative in the period of the Dead Sea Scrolls (to ca. second century CE), since the biblical scrolls from the Judean Desert are mostly single-book scrolls, with only a very few exceptions with two or possibly three books. ${ }^{6}$ Even the later En Gedi Leviticus scroll, which probably dates from the third-fourth century CE, was probably just a scroll of Leviticus and not the whole Torah. ${ }^{7}$ Several centuries later, by the time of the Babylonian Talmud, the liturgical use of scrolls containing only a portion of the Torah was expressly forbidden: איוראין בחומשין בבית הכנסת משום כבוד צבור the synagogue out of respect for the congregation” (Babylonian Talmud Gițtin 60a). In the era of the Talmud חומשין (humašin) were scrolls that contained only a single biblical book. The pre-eminence of the Sefer Torah for public reading was thus firmly established in the Oral Torah, the oral law, as transmitted by the sages. In the twelfth century, the scholar Moses Maimonides stated in his law code that one may copy an individual book of the Torah, but it does not have the same sacred status as a Sefer Torah: מותר לכתוב התורה כל חומש וחומש בפני עצמו ואין בהן קדושת ספר תורה Torah as separate books (humaš ve-ḥumaš), but these do not have the sanctity of a Torah scroll (sefer tora)" (Mišne Tora Hilkot Təfillin, Məzuza ve-Sefer Tora 7:14). These single biblical books and excerpted texts are usable for study or for teaching children but not the liturgy. Even with the shift in worship from a single holy site, the Temple in Jerusalem, to synagogues scattered across the Jewish world, the strict rules governing the production and use of Torah scrolls remained and, indeed, multiplied. Regional and chronological variations emerged, which were then recorded in new halakhic compendia. Strict adherence to a standard was still necessary, even when the number of scrolls vastly increased. Maimonides regularized those rules in his Mišne Tora: there should be לא פחות משמונה וארבעים ולא יתר על ששים, "not less than 48 and not more than 60" lines on a scroll (Mišne Tora Hilkot Təfillin, Məzuza ve-Sefer Tora 7:10), for instance, as opposed to the earlier, looser standard of " 42 and 98" given in tractate Sofrim. ${ }^{8}$ But Maimonides still stipulated that attentive adherence to the traditional form remained the essential mark of quality, and thereby of liturgical rectitude; he despaired at the decline in the standard of Sifre Torot that he consulted while in Egypt (Mišne Tora, Hilkot Təfillin, Məzuza və-Sefer Tora 8:4).

6 Emanuel Tov, Textual Criticism of the Hebrew Bible, Second Revised Edition (Minneapolis: Fortress, 2001), 203-04.

7 Gary A. Rendsburg, “The World's Oldest Torah Scrolls,” ANE Today 6:3 (March 2018). http:// www.asor.org/anetoday/2018/03/Worlds-Oldest-Torah-Scrolls (accessed 14 October 2019).

8 Michael Higger, מסכת סופרים: ונלוו עליה מדרש מסכת סופרים (Jerusalem: Maqor, 1970), §2:11 116-17. 
As the medium for God's word in antiquity, the scroll was deployed early on as a divine metaphor by the poets and prophets of the Hebrew Bible. We can read about scrolls directly performing God's will as His instruments of divine power - flying through the air dispensing justice in Zechariah, ואשוב ואשא עיני ואראה והנה מגלה עפה, “Then I turned, and lifted up mine eyes, and looked, and behold a flying roll (magilla 'afa)" (Zech 5:1-2), or literally forcing prophecies in the form of "lamentations, mourning and woe" down Ezekiel's throat (Ezek 2:8-3:3). The scroll is a repository for God's law and His instrument for spreading it. Ownership or production of a scroll became a requirement for Jews, fixing through an act of writing the bond between the nation and God's word. The Babylonian Talmud, in the name of the sage Rava (Abba ben Joseph bar Hama, d. 352 CE), quotes Deut 31:19, - ועתה כתבו לכם את־השירה הזאת ולמדה את־בני ישראל, "Now therefore write ye this song for you, and teach it the children of Israel," as underpinning a commandment for every Jew to write a Torah scroll (Babylonian Talmud Sanhedrin 21b). Maimonides’ Mišne Tora decrees (Hilkot Təfillin, Məzuza və-Sefer Tora 7:1) that it is a necessity (a מצות עשה, a positive commandment) for “each and every man of Israel” (כל איש ואיש מישראל) to write for himself a Torah scroll, a Sefer Torah. If he is not capable of the task, then it is acceptable to get someone else to write it on his behalf. A Jewish king should therefore have two scrolls: one a personal scroll, which he would already have owned before becoming king, and one produced for his kingship. The former is put into storage, while the latter should accompany him in battle, when he sits in a court of law and at mealtimes, all of which Maimonides takes from Deut 17:19, והיתה עמו וקרא בו כל־ימי חייו, "And it shall be with him, and he shall read it all the days of his life."

The requirement to produce a personal Sefer Torah is an exacting and, for most people, an impractical task. According to the Masoretic notes at the end of the book of Deuteronomy (f. 120a) in the manuscript Russian National Library Evr. I B19a, known popularly as Codex Leningrad and the earliest complete codex of the Hebrew Bible, there are 5845 verses, 79,856 words, and 400,045 letters in the Pentateuch. Even an expert scribe can take many months to copy all that with the requisite care into a Torah scroll. The cost of the parchment alone would place the production beyond the means of most members of the Jewish community in the Middle Ages. Like many of the laws codified from the Mišna onwards, these commandments reflect ideals, the conditions for which might never obtain in ordinary life. They can be grouped with those governing the behaviour of Jewish royalty or the sacrifices in the temple, neither of which had relevance after the temple's destruction and the demise of the kingdom of Judaea, but which are preserved as historically important or potentially relevant in the future. On the other hand, halakhists have always been capable of showing ingenuity in 
coming up with ways to obey the strict letter of the law. Today members of a congregation can observe the commandment to write their own Torah scroll by the act of completing a scroll, each member writing, or even filling in the outline of, just a single letter, in a ceremony known as סיום התורה (siyyum ha-tora), "completion of the Torah." 9 This action was anticipated by Maimonides who wrote "and anyone who corrects a Torah scroll, even a single letter, it is as if he wrote all of it” (Mišne Tora, Hilkot Təfillin, Məzuza və-Sefer Tora 7:1). In the Middle Ages, the completion of another's scribal work is recorded as a meritorious act. The Cairo Genizah fragment Cambridge University Library T-S A42.3 is the colophon of a large-format Bible, written on parchment. The colophon comes at the end of the book of Deuteronomy, indicating that this was probably originally a manuscript of the whole Torah. It reads:

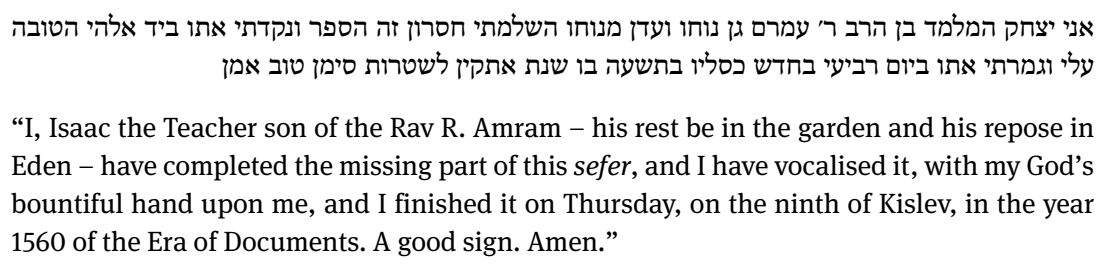

"I, Isaac the Teacher son of the Rav R. Amram - his rest be in the garden and his repose in Eden - have completed the missing part of this sefer, and I have vocalised it, with my God's bountiful hand upon me, and I finished it on Thursday, on the ninth of Kislev, in the year 1560 of the Era of Documents. A good sign. Amen.”

The dating, which uses the Seleucid Era, corresponds to $1248 \mathrm{CE}$. A note above the colophon, in a different hand, indicates that the volume was subsequently dedicated to the Synagogue of the Palestinians in al-Fusțāt, which was the synagogue in which the Cairo Genizah was discovered. Both the completion and the dedication were regarded as meritorious acts, and a great many colophons in tenth-thirteenth century Bibles mark their dedication to a synagogue or community. ${ }^{10}$

\section{Scrolls and Codices}

What is notable about this Pentateuch manuscript, T-S A42.3, and many others produced in the Near East during the same period of the high Middle Ages, is that

9 Rothkoff and Rabinowitz, "Sefer Torah," 243.

10 There are many in the Cairo Genizah Collections, e.g., T-S NS 248.28, a bifolum from a smaller format parchment codex, containing Genesis, with a note dedicating it לכנסת אלשאמין, "to the Synagogue of the Palestinians.” Paul Kahle gives a number of examples from the Firkovich Collection in the Russian National Library. See, e.g., RNL Evr. II B225, which was dedicated to עדת בעלי הקראים השוכנים בירושלים, “the community of Qaraites who dwell in Jerusalem”; Paul Kahle, Masoreten des Westens (Stuttgart: Kohlhammer, 1927), 67-68. 
they are books, codices, and not scrolls of the Torah. The Hebrew Bible itself extols the scroll, the sefer (ספר) or megilla (מגלה), and rabbinic sources similarly discuss scrolls of the Torah. In origin, and particularly in the compound Sefer Torah (ספר (תורה), the noun ספר (sefer, pl. safarim) refers solely to a scroll. From the Middle Ages onwards, and certainly in Modern Hebrew, sefer comes to mean "book". This can lead to ambiguity. Moses Maimonides' statement in the Mišne Tora that he has seen much confusion in all the safarim he has consulted is just such a case, in fact, one of the more egregious examples. His use of safarim is traditionally translated as "scrolls", e.g., in the Moses Hyamson edition, "As in all the scrolls I have seen, I noticed serious incorrectness in these regards."11 However, we could equally take this to mean "books" in its broadest sense, copies of the Bible in all formats, perhaps more like the way the word kitāb is used in Arabic, which was, after all, Maimonides' native language. ${ }^{12}$ The ambiguity of Maimonides' Hebrew formulation is on open display in the passage of the Mišne Tora that discusses the correct layout of the "open and closed sections" (the parašiyyot satumot and patuhot) of the Masoretic text. He states that he has relied on a famous copy of the Bible, well-known in Egypt, for the correct writing of them:

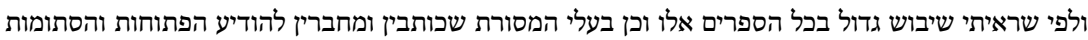

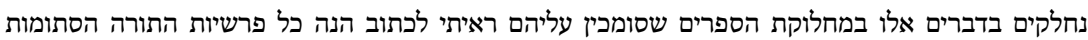

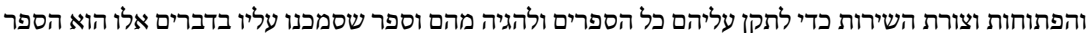

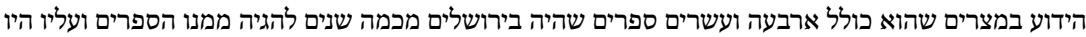

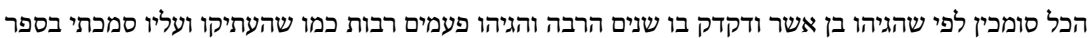
התורה שכתבתי כהלכתו שתוגורו

And because I have seen great confusion in all these safarim, and indeed the Masoretic authorities who write and produce compositions to proclaim the open and closed sections are themselves divided in these matters due to the lack of concord in the safarim that they rely on, I have thought it fit to write here all the open and closed sections of the Torah, and the format of the songs, in order that all the safarim may be corrected and carefully checked against them. And the sefer on which we relied in these matters is the sefer well-known in Egypt, which contains the twenty-four səfarim, that was used in Jerusalem some years ago to check safarim and on which everyone used to rely because Ben Asher had checked it and closely studied it over many years, and he checked it many times whenever it was copied from. And I myself relied on it for the Sefer Torah that I wrote according to the halak $a$ (Mišne Tora, Hilkot Təfillin, Məzuza və-Sefer Tora 8:4).

11 Moses Hyamson (ed.), Mishneh Torah: The Book of Adoration by Maimonides, edited according to the Bodleian (Oxford) Codex with an English Translation (Jerusalem: Boys Town Jerusalem Publishers, 1965), 131b.

12 Johannes Pedersen and Geoffrey French, The Arabic Book (Princeton, NJ: Princeton University Press, 1984), 12. 
Maimonides caused the confusion here himself, because he chose to write his great codification of Jewish law in a deliberately archaising Hebrew, the language of the Rabbis who transmitted the Oral Torah. Rabbinic Hebrew, especially in the form in which Maimonides reimagined it, lacked a nuanced vocabulary for the different forms of writing medium that had become available even long before Maimonides' day. ${ }^{13}$ Traditional Rabbinic Judaism knew only the scroll for the communication of its religious texts. Hence, in this quite crucial passage, which has provoked considerable interest over time, he uses the noun sefer in singular and plural to refer to (a) a codex of the whole Hebrew Bible; (b) a biblical book as a literary unit; (c) scrolls or codices of the Bible in general; and (d) a Torah Scroll, which he had copied, in particular. This passage is well known and frequently cited because the codex that Maimonides sets up as the model for all to follow is believed by tradition, and now by most modern scholarship, to be the famous Aleppo Codex, which documentary evidence can place in Egypt in Maimonides' day and which is held to be the work of the last, great Masorete, Aaron ben Moses ben Asher. ${ }^{14}$

Had Moses Maimonides written his testimonial for the Aleppo Codex in Judaeo-Arabic, in which most of his other compositions were written, then perhaps alongside the word כתאב (kitāb) for "book" in a general sense, he would have used a number of different nouns for the varying types of sefer that he was describing. A clear contrast can be seen in a Judaeo-Arabic letter written in $1100 \mathrm{CE}$, a half-century before Maimonides' work, following the capture of Jerusalem in the First Crusade. This letter draws a clear distinction between scrolls and books, quite unlike the uniform sefer/safarim of Maimonides' text. Written at a time of immense crisis, it details how the Jewish community of Ashqelon had coped with the fall of Jerusalem and the arrival of the soldiers of the First Crusade on their doorstep. ${ }^{15}$ The community had fallen into debt by ransoming captive Jews back from the Crusaders. Ashqelon was well fortified and remained in Fātimid hands while the rest of the Holy Land fell to the sudden onslaught of the invading "Franks". After taking Jerusalem, they came to what was their new border with the Islamic world and traded the captives they had taken for dinars. The ransoming of prisoners was a necessary and righteous act in Jewish

13 Cf. Saul Lieberman, Hellenism in Jewish Palestine: Studies in the Literary Transmission, Beliefs and Manners of Palestine in the I Century B.C.E.-IV Century C.E. (New York: Jewish Theological Seminary of America, 1962), 206.

14 David Stern, The Jewish Bible: A Material History (Seattle: University of Washington Press, 2017), 64; Jordan Penkower, “Maimonides and the Aleppo Codex,” Textus 9 (1981): 39-129.

15 Shelomo Dov Goitein, “Contemporary Letters on the Capture of Jerusalem by the Crusaders," Journal of Jewish Studies 3 (1952): 168-75. 
eyes, but the letter also reveals the purchasing of sacred texts that the invaders had plundered, and from which the Franks also profited. Alongside the details of the debt incurred through ransoming prisoners, the writers talk about the debt incurred פי אבתיאע מאיתין ותלתין מצחף ומאיה דפתר וכ' ותמניה ספרי תורות גמיע דלך קודש, "in the purchasing of two hundred and thirty codices [of the Bible], one hundred quires etc, and eight Torah scrolls, all of them holy [=consecrated public property]" (Cambridge University Library T-S 20.113). ${ }^{16}$ The language is Judaeo-Arabic, the written vernacular of the Jews of the Fātimid realm, although "Torah scrolls" is the Rabbinic Hebrew compound plural ספרי תורות (sifre torot). The noun מצחף (muṣhaf) is Arabic for "codex" and is used in the Judaeo-Arabic of this period to denote codices of the Bible. Having originally referred in Arabic to Qur'an codices, ${ }^{17}$ it was borrowed into Jewish Arabic to refer to codices of their holiest book, and was subsequently hebraised as דמצְחָ (miṣhaf). The noun דפתר (daftar, diftar), a Greek loan into Arabic, denotes a book-type distinct from muṣhaf, referring here probably to partial or unbound books, i.e., volumes, fascicles or quires. ${ }^{18}$ Arabo-Islamic sources have a relatively large number of words for such book-like structures, including juz', "fascicle, part”, and karrāsa, "volume”, reflecting the sophistication of the Arabic book trade. ${ }^{19}$ The prime liturgical object, the Torah scroll, retains its Hebrew identity, however, even in an Arabic document, whereas the vocabulary denoting books, no matter how "holy" they are too by dint of the sacred text they carry, is Arabic. The cause of this discrepancy is a lack of an existing, embedded Hebrew vocabulary for the codex, which necessarily reflects the late period of the writing medium's adoption by Judaism.

It is generally accepted by scholarship that Judaism, as an institution, adopted the codex much later than the cultures around it, centuries after the technology's introduction into the Hellenistic world and long after its adoption by Christianity. In his recent material history of the Jewish Bible, David Stern put it so: "[I]t is clear that it took Jews at least four hundred years longer to adopt the new writing platform than most everyone else in the Mediterranean world."20

16 The manuscript can be viewed online at https://cudl.lib.cam.ac.uk/view/MS-TS-0002000113/1 (accessed 14 October 2019).

17 Pedersen and French, The Arabic Book, 101-02.

18 Malachi Beit-Arié, Hebrew Codicology: Historical and Comparative Typology of Hebrew Medieval Codices based on the Documentation of the Extant Dated Manuscripts using a Quantitative Approach, Preprint internet English version 0.3+ (August 2019), 41. https://web.nli.org.il/sites/ NLI/English/collections/manuscripts/hebrewcodicology/Documents/Hebrew-Codicologycontinuously-updated-online-version-ENG.pdf (accessed 14 October 2019).

19 Doris Behrens-Abouseif, The Book in Mamluk Egypt and Syria (1250-1517): Scribes, Libraries and Market (Leiden-Boston: Brill, 2019), 50-52.

20 Stern, The Jewish Bible, 66. 
Beit-Arié writes similarly: "The Jews, on the other hand, adopted the codex much later [than the Christians], not before the Muslim period and the beginning of the Geonic literary activity, and presumably no earlier than the eighth century."21 By "Jews", in both cases, I think we have to understand "Judaism", for reasons which will become clear below. Medieval Jewish sources would generally agree with these statements. The French commentator Rashi (Solomon ben Isaac, d. 1105) remarked in his notes on the liturgical reading of the Scroll of Esther (Babylonian Talmud Megilla 19a) that ספרים שהיו בימי חכמים כולן בגיליון כספר תורה שלנו, “the 'books' they had in the time of the Sages were all in roll (gilayon) form, like our Torah scroll."22 The failure of the codex to make a significant inroad into late antique Jewish culture can be partly attributed to the Torah scroll's weighty position as the pre-eminent sacred object and the concomitant manner in which prayer was conducted in the early synagogue - led by expert readers, with limited participation of the wider congregation. The continued required presence of the Torah scroll in the synagogue today is evidence that this position was not displaced by the book in the liturgical sphere. But the codex, as a multi-leaved and easily portable media carrier, did manage to enter Jewish life, and not just in the private realm of personal prayer, contemplation and study, where the Torah scroll does not hold sway, but also into the public liturgical space.

Proofs of the late adoption of the codex by Jews may be sought in codicologicalarchaeological evidence, although the poor survival of Jewish manuscripts from the period between the Dead Sea Scrolls to the earliest medieval manuscripts, i.e., from the end of the second century CE to the beginning of the tenth century, means that this is mostly an argument from silence. The earliest explicitly dated Hebrew codex is from the Cairo Genizah, where a few fragments survive of a small horizontal-format copy of the Bible, resembling in shape an 'Abbāsid -era Qur'ān. On one surviving bifolium (T-S NS 246.26.2) there is a colophon stating that Joseph b. Nimorad copied the text in the town of Gunbad-i-Mallgan, in Iran, in the year $1215 .^{23}$ Although Joseph did not indicate which system of dating he was employing, it can only reasonably be the Seleucid, "Era of Documents", and hence equates to 903-904 CE. This is the earliest that is dated explicitly and genuinely. The Cairo Codex of the Prophets, a large format Bible with striking Masoretic notes, has a colophon in the name of the Masorete Moses b. Asher and is

21 Beit-Arié, Hebrew Codicology, 39.

22 Beit-Arié, Hebrew Codicology, 39.

23 Ben Outhwaite, "Bifolium from a Biblical Codex," in In the Beginning: Bibles before the Year 1000, ed. Michelle P. Brown (Washington, D.C.: Freer Gallery of Art and Arthur M. Sackler Gallery, Smithsonian Institution, 2006): 252. The manuscript can be viewed online at https://cudl. lib.cam.ac.uk/view/MS-TS-NS-00246-00026-00002/1 (accessed 14 October 2019). 
dated 894-895 CE. It has for some time now been recognised that the Cairo Codex itself is a product of a later period, probably the eleventh century, and the Moses b. Asher colophon was written by the same hand as wrote other, later colophons in the book. ${ }^{24}$

Although this casts doubt on the authenticity of the biblical text and especially its vowels, accents, and Masoretic notes, which cannot be a faithful copy of the work of Moses b. Asher, the text of the colophon could be genuine. It was probably copied from an authentic source, even if the Bible text to which it was added was copied from another manuscript. The colophon is thus secondary אני משה בן : אנ אשר כתבתי זה המחזור שלמקרא, "I, Moses b. Asher, have written this codex of the Bible" (Cairo Codex of the Prophets, f. 575). The word מחזור (mahzor) appears to have been coined in the Islamic period as a Hebrew term for the Arabic muṣhaf (Glatzer 1989, 260-263). It is usual to find writers of Hebrew in the early Islamic Middle Ages avoiding Arabic terms, either through repurposing older Hebrew words or creating neologisms..$^{25}$ By the late tenth-eleventh century, mahzor is sometimes still used for "codex", but by then the word מצחף had become thoroughly hebraised and can be found in otherwise purely Hebrew colophons. Russian National Library Evr. I B19a (Codex Leningrad), which dates to the first decade of the eleventh century, perhaps reflects a period of transition, since it uses both: זה המחזור מקרא שלם נכתב ונגמר בנקודות ובמוסרות ומוגה יפה במדינת מצרים, "This codex (mahzor) of the complete Bible was written, furnished with vocalisation and masora, and carefully checked in Fustāat” (the plain colophon, f. 1r) and אני שמאול בן יעקב כתבתי ונקדתי ומס' זה המצחף לכבוד רבנא מבורך הכהן, "I, Samuel b. Jacob, have written, vocalised and provided the masora of this codex (miṣhaf) for the honour of our master Mevorak ha-Kohen" (star-shaped carpet page colophon, f. 474r). ${ }^{26}$ Later the word mahzor takes on a specialised meaning of "prayer-

24 Stern, The Jewish Bible, 226 n. 15; Colette Sirat, Hebrew Manuscripts of the Middle Ages, trans. Nicholas de Lange (Cambridge: Cambridge University Press, 2002), 42-44.

25 Ben Outhwaite, "Lines of communication: Medieval Hebrew letters of the 11th century," in Scribes as Agents of Language Change, ed. Esther-Miriam Wagner, Ben Outhwaite and Bettina Beinhoff (Berlin: De Gruyter, 2013): 5-6.

26 For a translation and discussion of B19a's plain colophon, see Ben Outhwaite, "Beyond the Leningrad Codex: Samuel b. Jacob in the Cairo Genizah," in Studies in Semitic Linguistics and Manuscripts: A Liber Discipulorum in Honour of Professor Geoffrey Khan, ed. N. Vidro, R. Vollandt, E.-M. Wagner and J. Olszowy-Schlanger (Uppsala: University of Uppsala Press, 2018): 320-40; for the illuminated colophon, see Ben Outhwaite, "Samuel ben Jacob: the Leningrad Codex B19a and T-S 10J5.15," Genizah Research Unit's Fragment of the Month, January 2016. https://www.lib. cam.ac.uk/collections/departments/taylor-schechter-genizah-research-unit/fragment-month/ fragment-month-5 (accessed 14 October 2019). 
book for the festivals," perhaps because its original base meaning of "codex", as opposed to scroll, had been usurped by the Arabic loanword. It was hard for neologisms to thrive in the sort of linguistic environment that Hebrew faced in the Islamic period. ${ }^{27}$ Further earlier but undated evidence is possibly found in a papyrus codex of liturgical poetry (T-S 6H9-21) - poems that embellished the reading of the Bible in the synagogue -, made from a single gathering, and also from the Cairo Genizah. This may on codicological grounds be from the eighth century, but that leaves it still a product of the Islamic world. ${ }^{28}$

\section{Literary Evidence of Book Use}

In contrast to the lack of physical evidence prior to the Islamic era, there are literary traces attesting to the knowledge and use of the book format by Jews. The codex developed as an evolution of the wooden writing tablet, and Saul Lieberman has pointed to the frequency of the Rabbinic Hebrew term פנקס (pinqas)

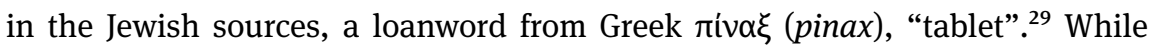
in origin the Hebrew word refers indeed to the classical wax writing-tablet, it is evident from the sources that in practice such tablets could have multiple "leaves" or be of different types of material. In Mišna Kelim 24:7 we find laws relating to the uncleanness of פנקסיות (pinqasiyyot) - "tablets" - either holding wax, "smooth" pinqasiyyot, or even pinqasiyyot made of papyrus. Thus by the end of the second century CE, when, by tradition, the Mišna was codified by Rabbi Judah ha-Nasi, the Rabbis were recording purity laws for the use of clearly codexlike writing supports. These supports appear to have been used principally for holding personal and business records, e.g., Mišna Šəvu'ot 7:5 where the shopkeeper states כתוב על פנקסי שאתה חיב לי מאתים זוז, "It is written in my account book (pinqasi) that you owe me two hundred zuz." In the ensuing period, which is covered by the legal discussions documented in the Babylonian and Palestinian Talmuds, these notebooks came to be used for the recording of legal decisions, rabbinic apothegms and the like, e.g., Babylonian Talmud Šabbat 156a records that various legal opinions were “written in Ze'eiri's notebook” (כתיב אפינקסיה דזעירי (דritten in Levi's notebook” and “written in Rabbi Joshua b. Levi's notebook," using the Babylonian Aramaic version of the word. In this, they were like

27 Ben Outhwaite, "Lines of communication: Medieval Hebrew letters of the 11th century," 196-97.

28 Beit-Arié, Hebrew Codicology, 40 n.8.

29 Lieberman, Hellenism in Jewish Palestine, 203. 
the writing tablets of Greece, which, as Roberts and Skeat point out, were used for texts of an "impermanent nature - letters, bills, accounts, school exercises, memoranda." ${ }^{30}$ We cannot be sure of the materials used, but it is evident that the scroll or other forms of roll, such as the rotulus, were giving way to new kinds of writing medium in the Hellenistic Jewish world. This technological shift was occurring principally among Jews in the secular sphere, but showing a gradual move - from shopkeepers to rabbis (the distinction is not necessarily great in that period) - into Judaism's more specifically religious environment. There is no real evidence in the sources, however, for the tablet's or the notebook's entry fully into the liturgical realm, and the codex is not seen as a suitable container for "Holy Writ" itself. The Written Torah was still the exclusive bailiwick of the scroll. However, its use by religious leaders and functionaries for their notes and legal decisions, as described in the Talmud, suggests that it was encroaching on the other, equally important religio-legal realm of Judaism, the Oral Torah, itself, since the codification of the Mišna in 200 CE, a tradition that was increasingly transmitted in writing.

Although the manuscript record is largely silent for the late Byzantine to early Islamic era, it is undeniable that by the time of the high Middle Ages (950-1250 CE), not only Jews but also Judaism had wholly embraced the codex, despite any earlier perceived reluctance. The magnificent Bible codices of the tenth and eleventh centuries, such as Aleppo, Codex Leningrad and the Cairo Codex of the Prophets, are tangible, imposing, expensive evidence of advanced book production in Egypt and Palestine, and they take pride of place in libraries of Judaica today for their accuracy and beauty. Leaves from similar prestige codices may be found in the Cairo Genizah collections, in dismembered or fragmentary states, suggesting that hundreds of such books were in circulation in Egypt and environs in the Middle Ages. On the other hand, the great strength of the Genizah Collection is its copious evidence of everyday book production, through the tens of thousands of leaves from less prestigious, user-produced books, such as pages from "Common Bibles," personal prayer books and other more "popular" examples of the codex format in use. A number of social-economic factors must have contributed to the comparative explosion in the manuscript record from Syria-Palestine and Egypt that we see in the tenth-eleventh centuries. These include the prosperity brought to Egypt by its incorporation into the burgeoning Fātimid Empire towards the end of the tenth century, together with the tolerant attitude of the authorities towards Jewish education - which produced a predominantly literate populace - and the practice

30 Colin H. Roberts and Theodore C. Skeat, The Birth of the Codex (London: Published for the British Academy by the Oxford University Press, 1983), 11. 
of the Jewish religion, which was largely centered on the study, promulgation and recitation of the written word. The society revealed through the Cairo Genizah is one that was literate in at least two languages - Hebrew and Arabic, the latter mainly in the form of Judaeo-Arabic, with significant knowledge of Aramaic, for religious reasons, and Persian, for cultural reasons, too. It was also a community that had a practice of or aspiration towards book ownership, revealed through the booklists and colophons of Genizah manuscripts, and one that extended beyond those with a clear occupational need such as jurisconsults or physicians. An additional driver for the popularisation of the codex format was the introduction of paper, which is found on sale in Egypt as early as $848 \mathrm{CE} .{ }^{31}$ Access to paper reduced the price of purchased books or enabled much cheaper production by users themselves; the results of this can be seen in the huge number of fragments from Jewish paper codices of the eleventh century onwards that the Cairo Genizah, almost uniquely, has preserved.

In addition to socio-economic factors, changes in the theological landscape may also have led to a changing Jewish attitude to the codex. While Christianity may not have been responsible for the introduction of the codex, or even for the promulgation of the format, its enthusiastic adoption of the book for the transmission of Christian works evidently led to the association in non-Christian eyes of Christians with codices. ${ }^{32}$ Such an association would have been problematic for Jews, but there are no explicit statements in Jewish sources that testify to a theological rejection of the codex as a Christian object or even, in Stern's words, as "a non-Jewish writing platform." 33 The halakot that reinforce the role of the scroll as the holder of holy writ, and which enforce its position in Rabbinic Judaism as the holiest of objects, do mostly date from the Christian period - the Jerusalem and Babylonian Talmuds, the tractate Sofrim. ${ }^{34}$ But the foundation of those roles dates from the biblical period of Ezra, and the evidence of the Mišna and Dead Sea Scrolls is already of an established set of scribal prescriptions regarding scrolls of the Torah. Beit-Arié makes a suggestion that the Jews may have harboured theological suspicions: "One may presume that the diffusion of the codex among the Christians elicited a counter-response from the Jews, who must have been reluctant to adopt this book-form because of its associations with

31 Maya Shatzmiller, "An Early Knowledge Economy: The Adoption of Paper, Human Capital and Economic Change in the Medieval Islamic Middle East, 700-1300 AD," Centre for Global Economic History Working Papers Series no. 64 (2015): 4.

32 Roger S. Bagnall, Early Christian Books in Egypt (Princeton and Oxford: Princeton University Press, 2009), 71-73.

33 Stern, The Jewish Bible, 67.

34 Stern, The Jewish Bible, 31-32. 
Christianity." 35 This is probably the best that we can do, but the underlying lack of evidence should caution against promoting it to any more than a presumption. Other assumptions, such as the essentially conservative nature of Judaism and Jewish observance, may well be equally valid. In any case, from the tenth century onwards, the block is removed and Jewish codices abound, filling libraries and genizot. Was the incorporation of eastern Judaism into the Islamic world the principal factor behind this adoption of the codex? Undoubtedly it was a major mechanistic factor: the widespread use of the codex in the Islamic world provided a ready source of materials, artisans and knowledge to those who wanted to use the format. Most Hebrew nouns for the book, in all its different grades, are derived from or through Arabic or Persian; exceptions appear to be neologisms from the Islamic period. But the question of motivation remains necessarily obscure. The Islamic world's flaunting of the Qur'ān in codex form would have been impossible to ignore, particularly as the physical size of such codices increased enormously from the 'Abbāsid to Fātimid eras. The appearance of the Islamic book on the cultural scene may have dispelled, in non-Christian eyes, the Christian clergy's apparent monopoly on the codex. But again, this is just supposition, as we have no explicit statements to that effect from contemporary Jewish sources. The presumption that Islam was the crucial factor is ingrained: "The material form of the codex came to the Jews from without, from the larger Islamic world." ${ }^{36}$ The facts plainly testify to the period and the cultural milieu in which the technological exchange took place, but these should not also be confused with the motivation behind it, which remains obscure.

By the classical genizah period, which is handily equivalent to the high Middle Ages, 950-1250 CE, when the Fātimids and Ayyūbids governed in Egypt, the abundance of evidence from the Jewish community for the take-up of the codex is overwhelming. Individual book ownership is evidenced by the huge number, variety and diverse quality of parchment and paper codices of smaller format. Like the rabbis and shopkeepers of earlier generations, the Jewish merchants and court clerks of the Genizah period employed the pinqas, now a small, unbound paper notebook, for the recording of commercial activity and legal affairs. Halakhic monographs, such as Halakot Gedolot, circulated in book form, sometimes of quite impressive size, e.g., T-S K6.193, which is a parchment leaf from such a book, $30 \mathrm{~cm}$ high. ${ }^{37}$ These existed alongside more impromptu, personal collections of practical halakot in notebooks. Poetry, religious and secular,

35 Beit-Arié, Hebrew Codicology, 42.

36 Stern, The Jewish Bible, 7.

37 The manuscript can be viewed online at https://cudl.lib.cam.ac.uk/view/MS-TS-K-0000600193/1 (accessed 14 October 2019). 
was copied as the dīwān of a single poet or incorporated into compendia of festival poems: e.g., the book-list T-S K3.28, which includes דיואן יהודה הלוי כראכיס, "the dīwān of Judah ha-Levi in [several] volumes," and מעמד כיפור, "service for Yom Kippur."38 There are personal prayer-books, siddurim, in great number, alongside all manner of secular, philosophical, scientific, mathematical and even magical works in codex form - a veritable explosion of books. This is remarkable in itself given the Jewish reticence towards the codex of an earlier age, but in a significant development for Judaism we also now find, from at least the first half of the tenth century, and probably a century before that, the use of the codex for purely biblical text.

There are approximately 25,000 biblical fragments on paper and parchment in the Taylor-Schechter Genizah Collection at Cambridge. ${ }^{39}$ Around only 1500 of those originally derived from scrolls. A small number are single-page writing exercises by children or trainee scribes. This leaves probably more than 20,000 pieces from codices of the Bible, including "Great Codices" of two or three columns, Bibles with the Aramaic targum or with Judaeo-Arabic translation, and collections of prophetic readings (the hafțarot) or edifying snippets intended for homilies or poetry. A great proportion of the 25,000 biblical fragments come from smaller format biblical texts, which can include psalters and collections of haftarot or other subdivisions of the complete Bible. Among books of this type, Goshen-Gottstein distinguished "study codices", those which showed an assiduous commitment to correct transmission of the text, from "listener's codices", which were intended, in his eyes, for everyday use. ${ }^{40} \mathrm{He}$ chose the latter name because they were to support the congregation in its listening, not its reading, functioning as "little more than hearing aids." ${ }^{41}$ He suggested that "listener's codices" made up more than half of the biblical fragments in the Elkan Nathan Adler Collection in the Jewish Theological Seminary in New York. Goshen-Gottstein's observation as to the purpose of the biblical texts is useful, but at this remove in time, and given the fragmentary nature of the evidence, we cannot often be sure as to the producer's purpose at the time of creation or the owner's at the time of purchase (on similar concerns in relation to early Christian documents, see the essay from Batovici in this volume). Colette Sirat's term "Common Bibles” is a more useful one, given

38 The manuscript can be viewed online at https://cudl.lib.cam.ac.uk/view/MS-TS-K-0000300028/1 (accessed 14 October 2019).

39 Malcolm C. Davis and Ben Outhwaite, Hebrew Bible Manuscripts in the Cambridge Genizah Collections. Vol. 4: Taylor-Schechter Additional Series 32-255 with addenda to previous volumes (Cambridge: Cambridge University Press, 2003), ix.

40 Moshe Goshen-Gottstein, "Biblical Manuscripts in the United States," Textus 2 (1962): 38-41. 41 Goshen-Gottstein, "Biblical Manuscripts in the United States," 41. 
that it describes format alone, and not use. She distinguishes them from Great Bibles (multi-columned Masoretic works) and various types with translation and/ or commentary. ${ }^{42}$ Taking the broadest definition, Common Bibles can range from parchment codices, produced by scribes and with a fully vocalised and cantillated text, to very scrappy pamphlet-type paper codices with only a partially or fully unvocalised Hebrew text, and evidently the work of the owner-user of the book. ${ }^{43}$ Their purposes may have been for study, or for practice or as an aide-memoire or as an adornment, a "lap" or "hand" Bible, in the synagogue. But it is equally likely that they shared a number of purposes, and we should not strictly define them as a single-use item: members of the Jewish community clearly liked to own a book, and for many people, following the halakhic directive to produce a Torah of their own, this was a Bible. What these Common Bibles all share is that they represent evidence of Bible ownership across the whole community, rich and poor, scholarly and ignorant, professionals and amateurs.

The Cairo Genizah contains not only the direct physical evidence for numerous codices on parchment and paper, but the documentary evidence of the book trade, book production, book ownership and the coveting of books over the high Middle Ages. ${ }^{44}$ Cambridge University Library T-S NS J53, for example, a twelfth of thirteenth century list of books on a folded piece of paper has 57 titles on it, all of which probably belonged to a single owner. ${ }^{45}$ Synagogue inventories from the Genizah show just how many books were in public ownership - as communal property, the הקדש (heqdeš) - in the eleventh and twelfth centuries. The Synagogue of the Palestinians in al-Fustāt lists 80 codices, of which 68 are the Torah, in an inventory from 1186 CE, with terse listings such as, for example, מצחף תמרז בג' דפאת מצחף גאמע ללמקרא , "a codex of the Torah in 3 columns; a codex of the whole Bible” (Bodl. MS Heb. f56.49 line 7). ${ }^{46}$ All of these books were in public

42 Sirat, Hebrew Manuscripts of the Middle Ages, 42-50.

43 Ben Outhwaite, “The Tiberian Tradition in Common Bibles from the Cairo Genizah,” in Geoffrey Khan and Aaron Hornkohl (eds). Semitic Vocalization and Reading Traditions (Cambridge: University of Cambridge and Open Book Publishers, 2020).

44 Shelomo Dov Goitein, A Mediterranean Society: The Jewish Communities of the World as Portrayed in the Documents of the Cairo Geniza. Vol. 2: The Community (Berkeley-Los AngelesLondon: University of California Press, 1971), 189, 206, 239-240; Nehemya Allony, The Jewish Library in the Middle Ages: Book Lists from the Cairo Genizah, ed. by Miriam Frenkel, Haggai Ben-Shammai, with the participation of Moshe Sokolow [Hebrew] (Jerusalem: Ben-Zvi Institute for the Study of Jewish Communities in the East Yad Izhak Ben-Zvi and the Hebrew University of Jerusalem, 2006).

45 Allony, The Jewish Library in the Middle Ages, 35-38. The manuscript can be viewed online at https://cudl.lib.cam.ac.uk/view/MS-TS-NS-J-00053/1 (accessed 14 October 2019).

46 Allony, The Jewish Library in the Middle Ages, 303-05. 
ownership, some apparently having been written expressly to be given to the synagogue, e.g., a book-list of 1181-2 CE, for the Synagogue of the Iraqis (Jews of Babylonian heritage or affiliation) in al-Fusțāt, has מצחף תורה גדיד אסתנסכתה "אם תנא ואקדשתה ללכניסה אלמדכורה "a new codex of the Torah that Umm Tanna commissioned ("caused to be copied") and dedicated to the aforementioned synagogue” (Bodl. MS Heb. f56.50 lines 37-38). ${ }^{47}$ Many other copies of the Bible, big and small, reveal similar evidence of having passed into public hands, through the addition of public ownership notes inside the body of the book in the manner of library stamps, e.g., a bifolium from a beautiful tenth-eleventh century parchקדש ליהוה אלהי , קדe contex in two columns has a note at the end of the book of Job ישראל לא ימכר ולא יגאל, "Holy to the LORD God of Israel, not to be sold or redeemed (i.e., pawned)”; it also has קדש ליהוה written in large square letters across the top of the columns (Cambridge University Library and Bodleian Libraries, Oxford, Lewis-Gibson Bible 6.88). ${ }^{48}$ This kind of addition is very frequent in large- and medium-format Bibles in the Genizah Collection.

I have cautioned above against trying to ascertain the purpose of biblical manuscripts - Common Bibles in particular - on the grounds that without documentary evidence it can just remain speculation. The physical evidence alone cannot, for the most part, explain their purpose, although we may reasonably suspect that a Bible of the size of Aleppo or Leningrad was unlikely to be used as a "hand Bible" by a member of the congregation as they listened to the service. Purpose could be, in any case, a misleading concept, because their production might have been, first and foremost, an act of observance in and of itself, fulfilling the commandment to produce and own a Torah scroll, just in its more modern form of a Torah book - something that Maimonides' use of the term ספר certainly allows. Or, given the evidence of book ownership that the Genizah presents us, their production might have been an acquisitive act of book ownership, as an essentially luxury item that the wealthier congregants might have aspired to. In this way, the creation of the object or the acquisition of it might trump any subsequent purpose to which it is put. In some cases, however, we do have documentary evidence as to how Hebrew Bible mișhafim were used, and, while scarce, this provides an illuminating illustration of the Jewish dichotomy of scroll versus book in action in the liturgical sphere.

47 Allony, The Jewish Library in the Middle Ages, 299-302.

48 The manuscript can be viewed online at https://cudl.lib.cam.ac.uk/view/MS-LG-BIBLE00006-00088/1 (accessed 14 October 2019). 


\section{Scriptural Codices and the Influence of Qaraism}

The Cairo Codex of the Prophets, which I have mentioned above, is a problematic manuscript, given its erroneous attribution to the Masorete Moses b. Asher himself. ${ }^{49}$ However, the text of its colophons, dedications and ownership notes has provided a number of interesting details concerning the use of it as a book. On f. 581 there is a dedication note (repeated elsewhere in the volume), which reads in part:

זה הדפתר שמונה נביאים שהקדיש אותו יעבץ בן שלמה בירושלם עיר הקדש אלהים יכונניה עד עולם סלה ללקראין העושים את המועדים על ראית הירח יקראו בו כלם בשבתות ובחדשים ובמועדים

"This volume of the Eight Prophets that Ya'beș b. Solomon has dedicated in Jerusalem, the Holy City - God establish it forever, sela - to the Qaraites who perform the festivals at the sighting of the (new) moon, for them all to read from it on Sabbaths, on New Moons and on festivals." ${ }^{50}$

The implication of this colophon is that the book was used liturgically by the Qaraite community of Jerusalem at all the points in the calendar when the Bible was read in the service.

Qaraism was a movement, or, more properly a madhab, a "school" in the Islamic sense, of Judaism that arose in the ninth century. ${ }^{51}$ It appears to have formed from various groups in the early Islamic period, of whom the followers of 'Anan b. David, a member of the Babylonian exilarchic family, were most prominent. ${ }^{52}$ What bound the original groups was a shared dissent from the standard Rabbinic tradition. A rejection of the Oral Torah, or at least an uncritical acceptance of it, therefore came to define the movement..$^{53}$ Qaraism accrued many followers, and following emigration from the homelands of Iraq and Persia, Qaraite

49 See, e.g., Paul Kahle, The Cairo Geniza (London: Oxford University Press, 1947), 56-57. When faced with the problems of two contrasting colophons (both in the same hand), Kahle chose to interpret the common phrase ועשה אותו לעצמו uniquely, as meaning that Ya'beș b. Solomon had "prepared the parchment for the codex" (taking the earlier mention of daftar to mean "parchment"), thereby avoiding the problem of two different people taking credit for producing the same biblical codex. Subsequent scholars have similarly tied themselves up in knots trying to justify the authenticity of the Moses b. Asher attribution.

50 See Kahle, The Cairo Geniza, 112-13, for the text of this colophon.

51 Marina Rustow, Heresy and the Politics of Community: The Jews of the Fatimid Caliphate (Ithaca, NY: Cornell University Press, 2008), xxvii-xxix.

52 Moshe Gil, A History of Palestine, 634-1099, trans. Ethel Broido (Cambridge: Cambridge University Press, 1992), 777-84.

53 Rustow, Heresy and the Politics of Community, 25. 
centres in Egypt and Jerusalem arose in the ninth-tenth centuries. ${ }^{54}$ In Palestine, Qaraite scholars took a very close interest in the Tiberian Masoretic tradition, though the exact relationship between Qaraism and the Masoretes of Tiberias remains unclear. To understand the colophon in the Cairo Codex of the Prophets and similar colophons we find in other Bibles, we need to consider the Qaraites' relationship to the Bible. With their distrust of the Oral Torah, the Qaraites placed the Hebrew Bible at the centre of their spiritual and liturgical life. Qaraite halaka was taken, wherever possible, solely from the Bible, prayers were derived from the Psalms. Nehemiah Allony gathered evidence, from both colophons and mostly later (sixteenth-nineteenth centuries) literary sources that Qaraites preferred or advocated the liturgical reading of the Bible from codices and not scrolls. ${ }^{55}$ In doing so, they were rejecting the Torah scroll-centrism of the Rabbanite movement. Given that it is the Oral Torah that prescribes the correct writing and reading of the Torah Scroll, this is not only feasible for the Qaraite movement, but actually desirable, or even essential, as it sought to distance itself from mainstream Rabbanism. It is in light of this that Allony read the colophon of the Cairo Codex, as evidence of the Qaraites' preference for the mișhaf over the sefer, in the tenth-eleventh centuries. Given that the Cairo Codex of the Prophets is just that - of the Former and Latter Prophets, the book of Joshua through to the book of the Twelve Minor Prophets - one can argue that the colophon only reveals that the Qaraites were reading their haftarot - the prophetical readings that follow the reading of the weekly section (paraša) of the Torah - from a book. This would not be surprising, as it became acceptable even within Rabbanite circles to read the haftarot from a codex, although many scrolls of haftarot are found in the Cairo Genizah. ${ }^{56}$ Allony also pointed to the evidence from the greatest of Great Bibles, the Aleppo Codex, the book that Maimonides seems to have esteemed so highly. Damaged in the Aleppo riots of 1948, the colophons of that important Bible are lost, but fortunately they had been studied or copied several times in the preceding centuries. ${ }^{57}$ S. D. Cassuto's notes on the Aleppo Codex, which he made in 1943, before the book was damaged, were discovered and published by Yosef Ofer. They

54 Rustow, Heresy and the Politics of Community, 23-24.

55 Nehemya Allony, "ספר התורה והמצחף בקריאת התורה בציבור בעדת הרבנים ובעדת הקראים, Beit Mikra: Journal for the Study of the Bible and its World 78 (1979): 321-34.

56 Elbogen, Jewish Liturgy, 145-146. A good example from the Cairo Genizah is T-S A41.37, a very fragmentary scroll of Zech 14 and 1 Kgs 8, which are haftarot for the festivals of Sukkot and Šəmini 'Așeret. The scroll has an Aramaic colophon beginning הדין ספרא, "this scroll”, in case its current physical state should give any doubt to its original format.

57 Geoffrey Khan, A Short Introduction to the Tiberian Masoretic Bible and its Reading Tradition. 2nd ed. (Piscataway, NJ: Gorgias Press, 2013), 9-10. 
זה המצחף reveal his reading of a very similar dedicatory colophon, which begins השלם של עש' וארבעה ספרים, “This complete codex of the twenty-four books,” and goes on to specify how the book should be used:

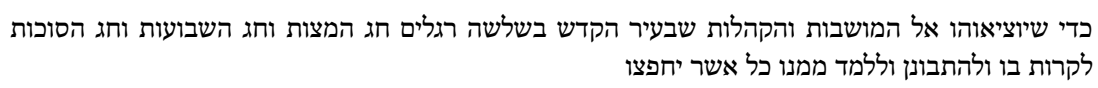

"In order that they should bring it out to the meeting-places and the congregations that are in the Holy City on the three Pilgrim festivals, the festival of Unleavened Bread, and the festival of Šavu'ot, and the festival of Sukkot, to read in it, and to reflect [on it] and study it, whoever would desire to." 58

Importantly here we are dealing with a complete copy of the Hebrew Bible, all 24 books (though sadly, it is no longer complete, having been badly damaged in the riots). The colophon reveals that the book is in the care of the Qaraite leadership, the two Qaraite Nesi' im, Josiah and Hezekiah, ${ }^{59}$ and that it should be read on the major festivals, which is to say at the principal liturgical occasions in the Jewish calendar. It appears that the Qaraites were deliberately setting themselves apart from their Rabbanite competitors by promoting in the meeting-places - mošavot, a calque of Arabic majlis, which served Qaraite congregations for synagogues ${ }^{60}$ the public reading of the Law from a codex. Objections could be raised to details of this interpretation, aside from the fact that the colophon is no longer extant to check its details and authenticity more thoroughly. The very special nature of the Aleppo Codex itself might make this more an occasion of parading a talismanic object, a public progress for the leadership and their centrepiece. But the explicit mention of reading from it, and the connection with the major liturgical occasions support Allony's interpretation.

The Cairo Genizah, which is the storeroom of the Palestinian, Rabbanite, synagogue of al-Fustātat, has, over the years of its investigation, provided a fair number of manuscripts which originally emanated from the Qaraite community of Egypt. This is surprising but not unexpected, given that the rules of genizah state that all holy texts (kitve qodeš) should be safely stored away, no matter what language they are in or no matter whether they are read in the congregation or not, and this includes the deliberate putting out of sight of harmful or sectarian texts. ${ }^{61}$ It should not be too surprising, therefore, that it can provide

58 Joseph Offer (Yosef Ofer), “M. D. Cassuto's Notes on the Aleppo Codex” (Hebrew), Sefunot 19 (1989): 287-88.

59 Gil, A History of Palestine, 634-1099, 792-93.

60 Gil, A History of Palestine, 634-1099, 179-81, 810.

61 Stefan C. Reif, A Jewish Archive from Old Cairo: The History of Cambridge University's Genizah Collection (Richmond, Surrey: Curzon, 2000), 11-14. 
some documentary evidence of the Qaraites' practice of reading the Bible in the Middle Ages. A paper bifolium containing a Fāțimid-era Shi'ite text in Arabic script, T-S Ar.51.86a, was reused in the twelfth of thirteenth century, and a liturgical text with clearly Qaraite features has been written, in Judaeo-Arabic and Hebrew, between the lines. ${ }^{62}$ The text consists of instructions in Judaeo-Arabic תמת צלאה בקר וצהרים ותפתח to perform the prayers, and includes the instruction "אלמצאחף ותקרא אחרי מות "at the end of the morning and afternoon prayer, open the codices and read 'After the death"” (T-S Ar.51.86a P3v). The instruction is to read the paraša אחרי מות, Leviticus 16:1-18:30, from the annual reading cycle of the Torah, and to read it from mașāhif, "codices" - not an ambiguous sefer. This is not the reading of hafțarot, where a humaš-style (partial text of the Bible) book might be used by a non-Qaraite congregation, but is a core liturgical reading of the Torah. Taken together with the colophons' evidence of Great Bibles forming the centrepiece of Qaraite festival liturgies, we can see that in the Middle Ages it became Qaraite practice to read the Torah from codices, thereby distinguishing themselves in a very visible manner from their Rabbanite brethren.

If for the Qaraites, the use of a codex signalled an independence from the mainstream, then for Rabbanites we might expect to see a greater prominence for the Torah Scroll as their sacred object and a marker of orthodoxy. A literary account of a ceremony of excommunicating the Qaraite nation en masse can be found in Abraham ibn Dā'ūd's Sefer ha-Qabbala ("Book of Tradition”, c. 1161 $\mathrm{CE}$ ), which is also a defence of orthodoxy against the Qaraites, whom he refers to throughout as “heretics". Abraham's version - he did not witness the ceremony himself - describes it so:

\footnotetext{
וכשהיו ישראל חוגגים חג הסוכות בהר הזתים היו חונים בהר מחנות מחנות אוהבים אלו את אלו ומבריכין ומין אלו

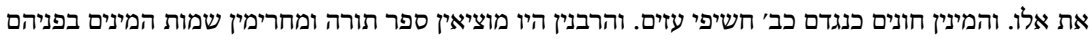
והם שותקים כמו כלבים אלמים.

\begin{abstract}
"When the Jews used to celebrate the festival of Tabernacles on the Mount of Olives, they would encamp on the mountain in groups and greet each other warmly. The heretics would encamp before them like two little flocks of goats. Then the rabbis would take out a scroll of the Torah and pronounce a ban on the heretics right to their faces, while the latter remained silent like dumb dogs." ${ }^{33}$
\end{abstract}

62 Esther-Miriam Wagner and Mohamed Ahmed, "T-S Ar. 51.86a: Shi'ite and Karaite - a Fatimid Melange," Genizah Research Unit's Fragment of the Month, December 2017. https://www.lib.cam. ac.uk/collections/departments/taylor-schechter-genizah-research-unit/fragment-month/fotm2017/fragment-6 (accessed 14 October 2019).

63 Gerson D. Cohen, A Critical Edition with a Translation and Notes of the Book of Tradition (Sefer Ha-Qabbalah) By Abraham Ibn Daud (Philadelphia: The Jewish Publication Society of America, 1967), 94, and Hebrew section 68. 
The Torah scroll is a necessary part of a formal excommunication, which usually in that period took place in the synagogue, but the symbolism inherent in brandishing it in the Qaraites' faces, while on one of the holiest sites in Jerusalem, is profound. Ibn Dā' ūd's story is embellished; the excommunication was not a regular occurrence; the numerous and powerful Qaraites of Jerusalem would not have cowered before the threadbare members of the Palestinian Academy; but it does have its origins in Rabbanite-Qaraite friction, particularly at the popular level, in eleventh century Palestine, which resulted in an attempted public excommunication on the Mount of Olives in 1029 CE (Rustow 2008, 201). ${ }^{64}$

In al-Fusțăt in the Classical Genizah period, there were two main synagogues, the Synagogue of the Palestinians (or of the Jerusalemites), which served the congregation who looked to Jerusalem as their spiritual centre and the Palestinian Gaon as their leader, and the Synagogue of the Iraqis (of the Babylonians), which looked to the Yešivot (Academies) of Iraq for their guidance. Although the Palestinian congregation had been dominant in the Jewish community of Egypt, the increasing arrival of Jewish immigrants from Babylon and North Africa from the ninth century onwards had eroded their position. ${ }^{65}$ By the tenth century, most of the Jewish world had adopted the customs and halakot of the Babylonian Academies, recognising the primacy of the Babylonian Talmud, adopting an essentially Babylonian liturgy, and the custom of reading the Torah through in a single year. ${ }^{66}$ The Palestinian congregation of al-Fusțāt, however, continued with a number of their ancestral customs, the most discernible of which was the liturgical reading of the Torah in three years, the triennial reading cycle. ${ }^{67}$ The congregation of the Palestinian synagogue thus read the seder, rather than the paraša, and followed it with different haftarot to those read in the Iraqi synagogue and much of the rest of the Jewish world. This custom continued in Moses Maimonides' day, and he noted it in the Mišne Tora: ויש מי שמשלים את התורה בשלש שנים ואינו מנהג פשוט , "And there are those who complete the Torah in three years, but this is not a common custom" (Tefilla u-Virkat Kohanim 13:1). Following attempts by Maimonides and his son, Abraham, to eradicate the divergent custom and impose the annual reading cycle and other Babylonian orthodoxies across the whole community, the Palestinian congregation resisted and sought to cement their traditional rites in a formal declaration in Judaeo-Arabic written in 1211 CE. A copy of this decla-

64 Rustow, Heresy and the Politics of Community, 201.

65 Elinoar Bareket, Fustat on the Nile: The Jewish Elite in Medieval Egypt (Leiden: Brill, 1999), $16-18$.

66 Robert Brody, The Geonim of Babylonia and the Shaping of Medieval Jewish Culture (New Haven: Yale University Press, 1998), 113-121.

67 Elbogen, Jewish Liturgy, 133. 
ration, preserved in a Cairo Genizah manuscript (Bodl. MS Heb. b13.41), set out the custom followed in the כניסה אלשאמיין (Kanīsat al-Šāmiyinn), the Palestinian Synagogue, and it acknowledged a number of distinctively Palestinian practices, including the regular reading of Psalms, and of the Ten Commandments as well as the reading פי ספר תורה אלסדר אלדי ואפק דלך אלסבת ואפטארתה, "from the Sefer Torah the seder which corresponds to that Sabbath and its hafțara." 68 The declaration asserts not only the reading of the triennial lection, but also that it should be from a Torah scroll, a fact that perhaps could have been taken as read, were it not for the earlier assertion that it is also their regular practice to read the paraša, of the (Babylonian) annual reading cycle: וקראה אלפרשה פי אלמצאחף, “and the reading of the paraša from codices" - mașāhif. Out of respect for the dominant Babylonian community's custom, and probably out of a minority's sensitivity for inter-communal relationships, the Palestinian congregation acknowledged the Babylonian reading of the Torah, with a "double reading of the Torah." 69 But whereas the Palestinian seder was read as it should be from the Torah scroll, the added, extra-halakhic, reading of the paraša was from a book, marking its nonliturgical status in the Palestinian synagogue, its second-class standing.

\section{Conclusion}

From late antiquity to the Middle Ages, the Torah scroll stood as a symbol of orthodoxies within Judaism. The histories of Josephus and Ibn Dā' ūd, separated by a thousand years, show the powerful status that the Sefer Torah held in their eyes. One used it as a momentous symbol of Jewish defeat and the other wielded it as a potent weapon against the heretics. Beyond the imagination of these medieval historians, we can see through the frictions of Qaraite versus Rabbanite, and Palestinian versus Babylonian, the symbolic role of the liturgical medium, book versus scroll and scroll versus book - giving new resonance to Solomon Schechter's famous observation in the London Times that the Genizah was "a battlefield of books." 70 The pre-eminent position of the Torah scroll in observance of Jewish rites, ensconced in the Oral Law and codified in Mišna, Talmud, extra-talmudic tractates and the medieval codes ensured that it could not be displaced, or its position even significantly eroded in mainstream rabbinic Judaism. Perhaps this,

68 Ezra Fleischer, Eretz-Israel Prayer and Prayer Rituals as Portrayed in the Geniza Documents [Hebrew] (Jerusalem: The Magnes Press, the Hebrew University, 1988), 219-22.

69 Fleischer, Eretz-Israel Prayer and Prayer Rituals, 293-320.

70 Solomon Schechter, “A Hoard of Hebrew MSS.,” The Times, 3 August 1897, 13. 
more than a Jewish distrust of Christian influence, kept the Jewish liturgical space clear of the codex for hundreds of years. Where the codex did infiltrate Judaism, it was through the Jews' use of it for non-liturgical purposes, so that it was neither an unknown nor an especially foreign technology by late antiquity. Following the Islamic conquests, the existing communities of the Near East found themselves surrounded by an Islamic culture that had, with the enthusiasm of new converts, wholeheartedly adopted the codex for their sacred text. The Jewish take-up of the codex for scripture began in earnest thereafter, perhaps initially through prayerbooks and poetry, before reaching its apogee in the magnificent Great Bibles of the tenth-eleventh centuries, which themselves were emulated by the general public, to varying degrees of quality and workmanship, in their thousands with the Common Bible. What caused this dramatic shift of the "Holy writ" from scroll to codex in the Middle Ages? At this stage of our knowledge, and with the severe lack of evidence in the immediately preceding period, answers can only be speculative. The Qaraites are, however, likely to have played a leading role. From their arrival in the ninth-tenth centuries in the Holy Land, they took a great interest in the accurate copying and transmission of the Bible, to the point that Qaraism and the Masoretic tradition of Tiberias has become intertwined. An examination of Great Bible colophons from the early Middle Ages shows again and again that Qaraites were the owners and commissioners of these magnificent codices. RNL Evr. I B19a, Codex Leningrad, was commissioned and initially owned by a rich merchant of Egypt called Mevorak b. Joseph b. Netan'el, known as Ibn Yazdād ha-Kohen, a Qaraite of Persian extraction. ${ }^{71}$ It is a luxury volume, with rich carpet pages and extensive Masora, and was produced by one of the leading scribes of al-Fusțāt. Perhaps for Ibn Yazdād it served as the central liturgical focus for his Qaraite majlīs, just as the Aleppo Codex did for the Qaraites of Jerusalem, and the Cairo Codex of the Prophets for its congregation. The physical and documentary evidence that places the book at the heart of the medieval Qaraite service must reflect the fundamental influence the Qaraites had on the proliferation of the Bible codex in the early Middle Ages.

71 Outhwaite, "Beyond the Leningrad Codex," 328-29. Note too (p. 326) that the book subsequently passed into the ownership of the Palestinian Ga'on Mașliah, a Rabbanite. As with Maimonides and the Aleppo Codex, the books' origins in the Qaraite community were no barrier to their use by Rabbanites. 


\section{Bibliography}

Allony, Nehemya. "ספר התורה והמצחף בקריאת התורה בציבור בעדת הרבנים ובעדת הקראים." Beit Mikra: Journal for the Study of the Bible and its World 78 (1979): 321-34.

Allony, Nehemya. The Jewish Library in the Middle Ages: Book Lists from the Cairo Genizah, ed. by Miriam Frenkel and Haggai Ben-Shammai, with the participation of Moshe Sokolow. Hebrew. Jerusalem: Ben-Zvi Institute for the Study of Jewish Communities in the East Yad Izhak Ben-Zvi and the Hebrew University of Jerusalem, 2006.

Bagnall, Roger S. Early Christian Books in Egypt. Princeton and Oxford: Princeton University Press, 2009.

Bareket, Elinoar. Fustat on the Nile: The Jewish Elite in Medieval Egypt. Leiden: Brill, 1999.

Behrens-Abouseif, Doris. The Book in Mamluk Egypt and Syria (1250-1517): Scribes, Libraries and Market. Leiden-Boston: Brill, 2019.

Beit-Arié, Malachi. Hebrew Codicology: Historical and Comparative Typology of Hebrew Medieval Codices based on the Documentation of the Extant Dated Manuscripts using a Quantitative Approach, Preprint internet English version 0.3+ (August 2019). https://web. nli.org.il/sites/NLI/English/collections/manuscripts/hebrewcodicology/Documents/ Hebrew-Codicology-continuously-updated-online-version-ENG.pdf

Brody, Robert. The Geonim of Babylonia and the Shaping of Medieval Jewish Culture. Paperback ed., with a new preface and an updated bibliography. New Haven and London: Yale University Press, 1998.

Cohen, Gerson D. A Critical Edition with a Translation and Notes of the Book of Tradition (Sefer Ha-Qabbalah) By Abraham Ibn Daud. Philadelphia: The Jewish Publication Society of America, 1967.

Davis, Malcolm C., and Ben Outhwaite. Hebrew Bible Manuscripts in the Cambridge Genizah Collections. Vol. 4: Taylor-Schechter Additional Series 32-255 with addenda to previous volumes. Cambridge: Cambridge University Press, 2003.

Elbogen, Ismar. Jewish Liturgy: A Comprehensive History. Trans. Raymond P. Scheindlin. Philadelphia: Jewish Publication Society; Jewish Theological Seminary of America, 1993.

Fleischer, Ezra. Eretz-Israel Prayer and Prayer Rituals as Portrayed in the Geniza Documents. Hebrew. Jerusalem: The Magnes Press, the Hebrew University, 1988.

Gil, Moshe. A History of Palestine, 634-1099. Trans. Ethel Broido. Cambridge: Cambridge University Press, 1992.

Glatzer, Mordechai. “The Aleppo Codex: Codicological and Paleographical Aspects." Hebrew. Sefunot NS 19 (1989): 167-276.

Goitein, Shelomo Dov. "Contemporary Letters on the Capture of Jerusalem by the Crusaders." Journal of Jewish Studies 3 (1952): 162-77.

Goitein, Shelomo Dov. A Mediterranean Society: The Jewish Communities of the World as Portrayed in the Documents of the Cairo Geniza. Vol. 2: The Community. Berkeley-Los Angeles-London: University of California Press, 1971.

Goshen-Gottstein, Moshe. "Biblical Manuscripts in the United States." Textus 2 (1962): 28-59.

Haran, Menachem. "Bible Scrolls in Eastern and Western Jewish Communities from Qumran to the High Middle Ages." Hebrew Union College Annual 56 (1985): 21-62.

Higger, Michael. מסכת סופרים: ונלוו עליה מדרש מסכת סופרים ב. Jerusalem: Maqor, 1970.

Hyamson, Moses, ed.. Mishneh Torah: the Book of Adoration by Maimonides, edited according to the Bodleian (Oxford) Codex with an English Translation. Jerusalem: Boys Town Jerusalem Publishers, 1965. 
Kahle, Paul. Masoreten des Westens. Stuttgart: Kohlhammer, 1927.

Kahle, Paul. The Cairo Geniza. London: Oxford University Press, 1947.

Khan, Geoffrey. A Short Introduction to the Tiberian Masoretic Bible and its Reading Tradition. 2nd Ed. Piscataway, N): Gorgias Press, 2013.

Lieberman, Saul. Hellenism in Jewish Palestine: Studies in the Literary Transmission, Beliefs and Manners of Palestine in the I Century B.C.E.-IV Century C.E. New York: Jewish Theological Seminary of America, 1962.

Offer, Joseph. (Yosef Ofer) “M. D. Cassuto’s Notes on the Aleppo Codex.” Hebrew. Sefunot 19 (1989): 277-344.

Outhwaite, Ben. "Bifolium from a Biblical Codex." In In the Beginning: Bibles before the Year 1000, ed. Michelle P. Brown, 252. Washington, D.C.: Freer Gallery of Art and Arthur M. Sackler Gallery, Smithsonian Institution, 2006.

Outhwaite, Ben. "Lines of communication: Medieval Hebrew letters of the 11th century." Scribes as agents of language change, ed. In Esther-Miriam Wagner, Ben Outhwaite and Bettina Beinhoff, 183-98. Berlin: De Gruyter, 2013.

Outhwaite, Ben. "Samuel ben Jacob: the Leningrad Codex B19a and T-S 10J5.15." Genizah Research Unit's Fragment of the Month, January 2016. https://www.lib.cam.ac.uk/ collections/departments/taylor-schechter-genizah-research-unit/fragment-month/ fragment-month-5

Outhwaite, Ben. "Beyond the Leningrad Codex: Samuel b. Jacob in the Cairo Genizah." In Studies in Semitic Linguistics and Manuscripts: A Liber Discipulorum in Honour of Professor Geoffrey Khan, ed. N. Vidro, R. Vollandt, E.-M. Wagner and J. Olszowy-Schlanger, 320-40. Uppsala: University of Uppsala Press, 2018.

Outhwaite, Ben. "The Tiberian Tradition in Common Bibles from the Cairo Genizah.” In Geoffrey Khan and Aaron Hornkohl (eds). Semitic Vocalization and Reading Traditions. Cambridge: University of Cambridge and Open Book Publishers, forthcoming 2020.

Pedersen, Johannes, and Geoffrey French. The Arabic Book. Princeton, New Jersey: Princeton University Press, 1984.

Penkower, Jordan. "Maimonides and the Aleppo Codex." Textus 9 (1981): 39-129.

Reif, Stefan C. A Jewish Archive from Old Cairo: the History of Cambridge University's Genizah Collection. Richmond, Surrey: Curzon, 2000.

Rendsburg, Gary A. “The World's Oldest Torah Scrolls.” ANE Today 6:3 (March 2018). (http://www.asor.org/anetoday/2018/03/Worlds-Oldest-Torah-Scrolls).

Roberts, Colin H. and Theodore C. Skeat. The Birth of the Codex. London: Published for the British Academy by the Oxford University Press, 1983.

Rothkoff, Aaron, and Louis Isaac Rabinowitz. "Sefer Torah.” In Encyclopaedia Judaica, ed. Fred Skolnik and Michael Berenbaum, 241-43. Detroit: Macmillan Reference USA, 2007.

Rustow, Marina. Heresy and the Politics of Community the Jews of the Fatimid Caliphate. Ithaca, NY: Cornell University Press, 2008.

Shatzmiller, Maya. "An Early Knowledge Economy: The Adoption of Paper, Human Capital and Economic Change in the Medieval Islamic Middle East, 700-1300 AD." Centre for Global Economic History Working Papers Series no. 64 (2015).

Schama, Simon. The Story of the Jews: Finding the Words, 1000 BCE-1492 CE. London: Vintage Books, 2014.

Schechter, Solomon. "A Hoard of Hebrew MSS." The Times, 3 August 1897: 13.

Sirat, Colette. Hebrew Manuscripts of the Middle Ages. Trans. Nicholas de Lange. Cambridge: Cambridge University Press, 2002. 
Stern, David. The Jewish Bible: A Material History. Seattle: University of Washington Press, 2017.

Tov, Emanuel. Textual Criticism of the Hebrew Bible. Second Revised Edition. Minneapolis: Fortress, 2001.

Wagner, Esther-Miriam, and Mohamed Ahmed. "T-S Ar. 51.86a: Shi'ite and Karaite - a Fatimid Melange." Genizah Research Unit's Fragment of the Month, December 2017.

https://www.lib.cam.ac.uk/collections/departments/taylor-schechter-genizahresearch-unit/fragment-month/fotm-2017/fragment-6. 
